\title{
Abdominal Computed Tomography in the Emergency Room: Overuse of Medical Technologies and the Depreciation of Clinical Diagnosis
}

\author{
Tomografia Computadorizada de Abdome \\ na Urgência: o Uso Exagerado das \\ Tecnologias Médicas e a Desvalorização do \\ Diagnóstico Clínico
}

\author{
Henrique Soares Silva ${ }^{1 \odot}$ \\ Fernanda Kelly Fraga Oliveira \\ Lourivania Oliveira Melo Prado ${ }^{I}$ \\ Marcos Almeida-Santos \\ Francisco Prado Reis
}

\section{PALAVRAS-CHAVE}

- Dor Abdominal.

- Tomografia Computadorizada

- Urgência.

- Educação Médica.

\section{RESUMO}

O número de tomografias computadorizadas (TC) realizadas de urgência tem aumentado cada vez mais desde a introdução desse recurso nos pronto-atendimentos (PA). Isso levou ao aumento substancial dos custos hospitalares e da exposição dos pacientes à radiação ionizante, o que tem despertado a necessidade do uso mais criterioso da TC no PA. O objetivo deste estudo é mostrar a relação entre os diagnósticos clínico, tomográfico e definitivo em pacientes com dor abdominal aguda não traumática como forma de evidenciar situações nas quais o uso da TC de abdome no PA possa ser considerado dispensável. Trata-se de um estudo transversal, com coleta retrospectiva de dados em prontuário eletrônico. Foram selecionados 834 prontuários de pacientes com dor abdominal aguda (DAA) com menos de sete dias de duração até o atendimento inicial, submetidos à TC de abdome de urgência entre $1^{-}$de janeiro de 2016 e 31 de dezembro de 2017. Os diagnósticos clínicos (pré-TC), tomográficos (pós-TC) e finais foram registrados e submetidos à análise de concordância por meio do cálculo do coeficiente Kappa (K), adotando-se $p<$ 0,05 como significativo. As TC foram avaliadas como desnecessárias quando o diagnóstico clínico foi concordante com as situações em que o diagnóstico final e pós-TC foram também o mesmo. Os diagnósticos mais frequentes foram dor abdominal inespecífica (DAI), uropatia obstrutiva (UO) e apendicite $(A P)$, que correspondem a 73,6\% de todos os diagnósticos clínicos, 58,5\% dos diagnósticos pós-TC e $61,3 \%$ dos diagnósticos finais. Os resultados mostraram concordância moderada para DAI (Kappa $=$ 0,41; $p<0,001)$ e para UO (Kappa $=0,46 ; p<0,001)$ e excelente para AP (Kappa $=0,87 ; p<0,001$ ). Foram consideradas desnecessárias $52,6 \%$ das TC realizadas em pacientes com diagnóstico de DAI, 82,4\% dos pacientes com UO e 91,7\% daqueles com diagnóstico final de AP. Conclui-se que há altas taxas de TC que podem ser entendidas como desnecessárias para o diagnóstico das principais condições de urgência encontradas, especialmente AP. O estudo alerta para a utilização exagerada da TC no PA e faz uma reflexão sobre possíveis causas, como falta de confiança no diagnóstico clínico, medo de erros médicos e processos judiciais, cujas soluções possíveis podem ser mais eficazes se adotadas ainda na base da formação médica. 


\section{KEY-WORDS}

- Abdominal Pain.

- Computed Tomography.

- Urgency.

- Medical Education.

\begin{abstract}
The number of computed tomography (CT) examinations performed in urgent care has been increasing since its introduction in the emergency room (ER). This has led to a substantial increase in hospital costs and patient's exposure to ionizing radiation, which has led to the need for more judicious use of CT in the ER. The aim of this study is to show the difference between clinical (pre-CT), tomographic (post-CT) and definitive diagnoses in patients with abdominal CT in the ER. This is a cross-sectional study, with retrospective data collection through electronic medical records. A total of 834 patients with acute abdominal pain (AAP) lasting less than 7 days, submitted to abdominal computed tomography between January 1, 2016 and December 31, 2017 were selected. Clinical, tomographic and final diagnoses were recorded and submitted to a concordance analysis by calculating the Kappa coefficient, considering $p<0.05$ as significant. CT scans were considered unnecessary when the clinical diagnosis was concordant when both final and post-CT diagnosis were also concordant. The most frequent diagnoses were nonspecific abdominal pain (NSAP), obstructive uropathy (OU) and appendicitis $(A P)$, corresponding to $73.6 \%, 58.5 \%$ and $61.3 \%$ of all diagnoses, respectively. Data analysis showed a moderate Concordance for NSAP (kappa: 0.41, $p \neg<0.001$ ) and for OU (kappa: $0.46, p<0.001$ ) and excellent for AP (kappa:0.87, $p<0.001$ ). In total, 52.6\% of computed tomography were considered unnecessary for NSAP, $82.4 \%$ for OU and $91.7 \%$ for AP. It was concluded that there are high rates of CT that may be considered unnecessary for the diagnosis of the main emergency conditions, especially appendicitis. The study warns to the exaggerated use of CT in the ER and raise discussions over the possible causes, such as lack of confidence in the clinical diagnosis, fear of diagnostic errors and fear of malpractice lawsuits, of which possible solutions may be more effective when applied since the medical education basis.
\end{abstract}

Received on: 5/14/19

Accepted on: 6/17/19

\section{INTRODUCTION}

The Computed Tomography (CT) has great accuracy in the evaluation of most urgent abdominal diseases, surpassing the performance of ultrasonography (US) and conventional X-ray (RX) 1,2 and, therefore, it has been increasingly used in evaluation of patients with acute abdominal pain (AAP) $)^{3,4}$. Its introduction in the emergency room (ER) has been associated with increased confidence in the diagnosis and improved medical decision-making 5 . In Brazil, the total number of CT procedures increased from 540,067 to 921,485 exams between 2008 and 2011 in the Brazilian Unified Health System (SUS Sistema Único de Saúde), with abdominal and pelvic CTs being the second most often performed ones ${ }^{6}$.

However, the increased use of CT in the ER is associated with increased hospital costs ${ }^{7}$ and patient exposure to ionizing radiation ${ }^{8,9}$, which has led to a growing demand for conscientious use of CT, especially in the ER, where the number of CT procedures continues to grow ${ }^{10,11}$.

'Choosing Wisely', a global initiative of the American Board of Internal Medicine (ABIM) foundation, founded in
2012 to promote health discussions aimed at reducing the misuse of health resources, warns in one of its publications that CTs are not always necessary for routine assessment of abdominal pain $^{12}$. According to the organization, $73 \%$ of US physicians admit that the frequency with which diagnostic tests or medical procedures are requested is a serious health care problem ${ }^{13}$.

Systermans et al. (2014) warn that, while abdominal CT correctly shows disease in $92-97 \%$ of patients, CT scans show normal results in $44 \%$ of patients and correspond to clinical data in $70 \%$ of cases. Thus, the authors even questioned whether CT scans might have decreased clinical skills or whether physicians' poor confidence in their capacity to evaluate patients with acute conditions led to the replacement of traditional physical examination by modern imaging techniques ${ }^{14}$.

The main objective of this study is to show the association between clinical, tomographic and definitive diagnoses in patients with AAP in the ER aiming to highlight situations in which the use of CT may be considered unnecessary. It is also intended to cause reflection on the value of clinical diagnosis in the presence of new medical technologies. 


\section{Material and Methods}

A cross-sectional study was designed, with retrospective data collection from Medhosp (Medlynx®) electronic medical record from a high-complexity private hospital serving a region of approximately 1 million inhabitants, which has been accredited internationally (Accreditation Canada International) since 2012.

The medical records of patients with AAP lasting less than 7 days submitted to urgent abdominal CT between January 1, 2016 and December 31, 2017 were included. Patients with a history of trauma lasting less than 30 days, CT indicated for clinical or surgical treatment control and incomplete medical records were excluded from the sample.

The clinical diagnosis (pre-CT) was recorded according to the last suspected diagnostic hypothesis up to CT performance. The CT findings were collected only from radiologist reports, considering the first listed diagnosis when two or more were present.

Tomographic results were classified as positive for AAP, normal abdominal CT (NACT) and negative for AAP, according to the concept of actionable findings, as proposed by Obuchowski and Modic ${ }^{15}$ and Gardner et al. ${ }^{16}$. Normal CT and those considered negative were classified as nonspecific abdominal CT (NSCT).

The final diagnosis was based on discharge reports, description of the surgical procedure or anatomopathological report, with the investigation in the database being carried out within 30 days after discharge from the emergency room for patients without hospitalization or clear diagnostic confirmation in the ER.

Nonspecific abdominal pain (NSAP), defined as abdominal pain without an identifiable alternative diagnosis or attributable organic cause $\mathrm{e}^{17,18}$, was considered when it was not possible to establish a specific diagnosis for AAP, clinically for pre-CT diagnoses and until discharge from the ER, or on subsequent consultations for final diagnoses.

CT scans were considered unnecessary when in Concordance with the clinical diagnosis in situations where the final diagnosis and the pre-CT one were also in Concordance. The use of X-rays and US before the CT indication was also recorded.

Statistical analysis was performed using the $\mathrm{R}$ statistical software ( $R$ Core Team 2018). The Kappa coefficient (K) was applied to evaluate the Concordance between the pre-CT, postCT and final diagnostic groups, adopting a $p$ value $<0.05$ as significant. The following classification was used for the interpretation of K values: 0: poor; 0.01-0.20: slight; 0.21-0.40: fair; 0.41-0.60: moderate; 0.61-0.80: substantial; 0.81-1: excellent ${ }^{19}$.

This study was approved by the Human Research Ethics Committee through Opinion N. 2,474,591.

\section{Results}

A total of 834 records were found to be eligible for the study. The sample consisted of 442 women (53\%) and 392 men (47\%), with a mean age of 44 years $( \pm 20.6$ years) for both genders. The mean duration of abdominal pain until the first consultation was 46.8 hours ( \pm 44.5 hours), with a median of 24 hours (0.5-196 hours). Up to the time of CT indication, 89 (10.7\%) patients had undergone only abdominal X-ray, 401 (48.1\%) only abdominal US and 187 (22.4\%) both examinations. US was not performed in $244(29.3 \%)$ cases and $157(18.8 \%)$ were referred to CT without any previous imaging study. CT was normal in $108(12.9 \%)$ cases and nonspecific for AAP in 231 (27.7\%) cases.

For both pre-CT, post-CT and final diagnoses, the most frequent diagnoses were NSAP, obstructive uropathy (OU) and appendicitis (AP), which together account for $73.6 \%$ of all clinical diagnoses, $58.5 \%$ of post-CT diagnoses and $61.3 \%$ of definitive diagnoses (Table 1).

\section{TABLE 1 .}

\section{Most frequent diagnoses in patients undergoing urgent} abdominal computed tomography in 2016 and 2017.

\begin{tabular}{|c|c|c|}
\hline \multicolumn{3}{|l|}{ Clinical diagnoses } \\
\hline Nonspecific abdominal pain & 314 & $37.6 \%$ \\
\hline Obstructive uropathy & 176 & $21.1 \%$ \\
\hline Appendicitis & 124 & $14.9 \%$ \\
\hline Diverticulitis & 38 & $4.6 \%$ \\
\hline Obstructive abdomen & 20 & $2.4 \%$ \\
\hline Enterocolitis & 20 & $2.4 \%$ \\
\hline Urinary tract infection (except pyelonephritis) & 18 & $2.2 \%$ \\
\hline Pancreatitis & 18 & $2.2 \%$ \\
\hline Gastroduodenitis & 16 & $1.9 \%$ \\
\hline Cholelithiasis & 11 & $1.3 \%$ \\
\hline \multicolumn{3}{|l|}{ Tomographic diagnosis } \\
\hline Unspecific abdominal computed tomography & 231 & $27.7 \%$ \\
\hline Obstructive uropathy & 162 & $19.4 \%$ \\
\hline Appendicitis & 95 & $11.4 \%$ \\
\hline Diverticulitis & 40 & $4.8 \%$ \\
\hline Obstructive abdomen & 36 & $4.3 \%$ \\
\hline Enterocolitis & 32 & $3.8 \%$ \\
\hline Unspecific inflammatory alterations & 27 & $3.2 \%$ \\
\hline Ovarian cyst & 20 & $2.4 \%$ \\
\hline Colonic distension & 20 & $2.4 \%$ \\
\hline Pancreatitis & 19 & $2.3 \%$ \\
\hline \multicolumn{3}{|l|}{ Final diagnoses } \\
\hline Nonspecific abdominal pain & 267 & $32.0 \%$ \\
\hline Obstructive uropathy & 148 & $17.7 \%$ \\
\hline Appendicitis & 97 & $11.6 \%$ \\
\hline Diverticulitis & 37 & $4.4 \%$ \\
\hline Obstructive abdomen & 37 & $4.4 \%$ \\
\hline Pancreatitis & 36 & $4.3 \%$ \\
\hline Gastroduodenitis & 18 & $2.2 \%$ \\
\hline Neoplasia & 15 & $1.8 \%$ \\
\hline Pyelonephritis & 15 & $1.8 \%$ \\
\hline Acute gastroenterocolitis & 14 & $1.7 \%$ \\
\hline
\end{tabular}


Of the 267 patients diagnosed with NSAP, 52.6\% had the diagnosis of NSCT. Analysis of the most frequent specific conditions showed that the tomographic diagnosis of OU corresponded to $83.8 \%$ of the definitive diagnoses and in $86.6 \%$ of cases of AP. Of the patients with NSAP, $43.5 \%$ had the same clinical suspicion and $53.9 \%$ at the CT. Among those who had the final diagnosis of NSAP and an initial diagnosis of another clinical hypothesis, 55.3\% were diagnosed with NSCT. Concordance between the three diagnostic stages was moderate for unspecific causes of AAP, with a kappa coefficient of 0.41 ; $\mathrm{p}<0.01$ (Table 2).

Of the patients diagnosed with OU by CT, $67.2 \%$ had the same clinical suspicion. Of the patients who had a final and initial diagnosis of OU, $82.4 \%$ were in Concordance with the tomographic diagnosis, although the CT showed obstructive calculi in $87.2 \%$ of the patients without this clinical suspicion (Table 3).

On the other hand, the initial suspicion of other diagnoses corresponded to the $\mathrm{CT}$ and with the final diagnosis of uri- nary obstruction in $96.4 \%$ of cases. The Concordance between the diagnoses was considered moderate for OU (Kappa 0.46; $\mathrm{p}<0.01$ ). The values are shown in Table 3. Half of the patients diagnosed with AP had the same clinical suspicion. Of these, CT was concordant in $91.7 \%$. On the other hand, of the patients with confirmed AP and no clinical suspicion, the CT was positive in $83.3 \%$ of cases. The correspondence between the diagnoses was considered excellent, with a kappa coefficient of $0.87, \mathrm{p}<0.01$ (Table 4).

\section{DISCUSSION}

The study analyzed the concordances between pre-CT, postCT and final diagnoses of 834 medical records of patients with $\mathrm{AAP}$, in search for situations where CT might be considered unnecessary. Of the total, 108 (12.9\%) CT scans with normal results were found and $231(27.7 \%)$ were considered unspecific for AAP, which is lower than the frequency reported in the literature ${ }^{14}$ but in agreement with those reported for the final diagnosis of NSAP ${ }^{20,21}$.

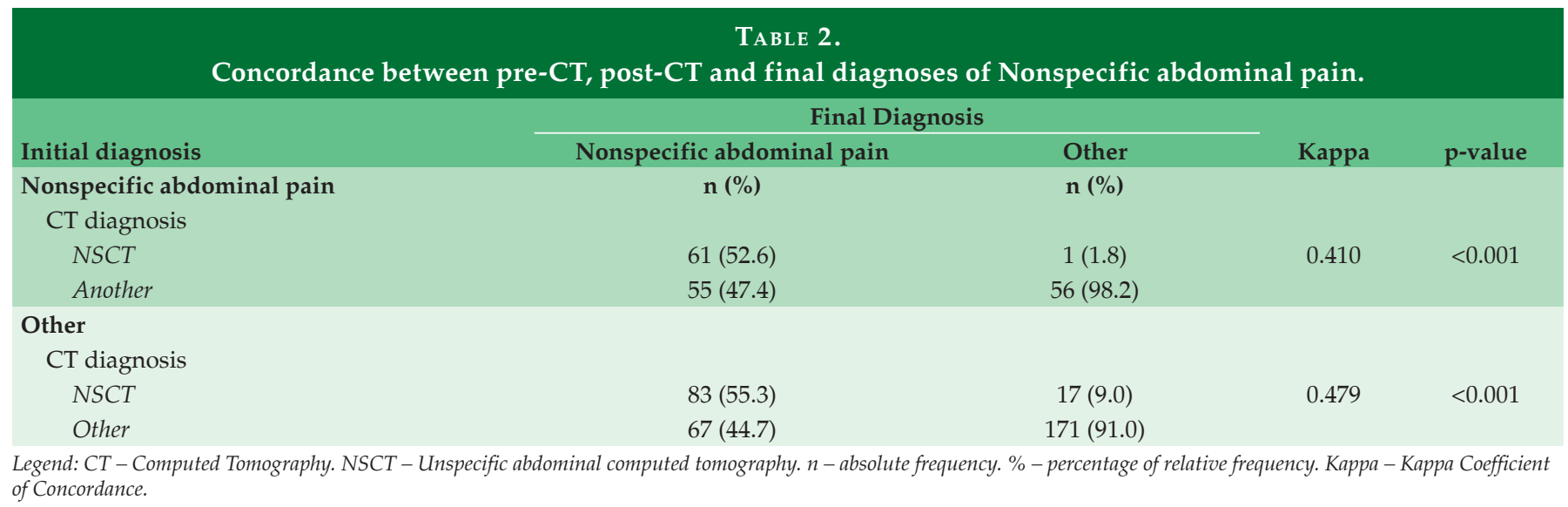

TABLE 3.

Concordance between pre-CT, post-CT and final diagnoses of obstructive uropathy.

\begin{tabular}{|c|c|c|c|c|}
\hline \multirow[b]{2}{*}{ Initial diagnosis } & \multicolumn{2}{|c|}{ Final Diagnosis } & \multirow[b]{2}{*}{ Kappa } & \multirow[b]{2}{*}{ p-value } \\
\hline & Obstructive uropathy & Other & & \\
\hline Obstructive uropathy & $\mathrm{n}(\%)$ & n (\%) & & \\
\hline \multicolumn{5}{|l|}{ CT diagnosis } \\
\hline Other & $18(17.6)$ & $35(63.6)$ & & \\
\hline \multicolumn{5}{|l|}{ Other } \\
\hline Other & $6(12.8)$ & $296(96.4)$ & & \\
\hline
\end{tabular}




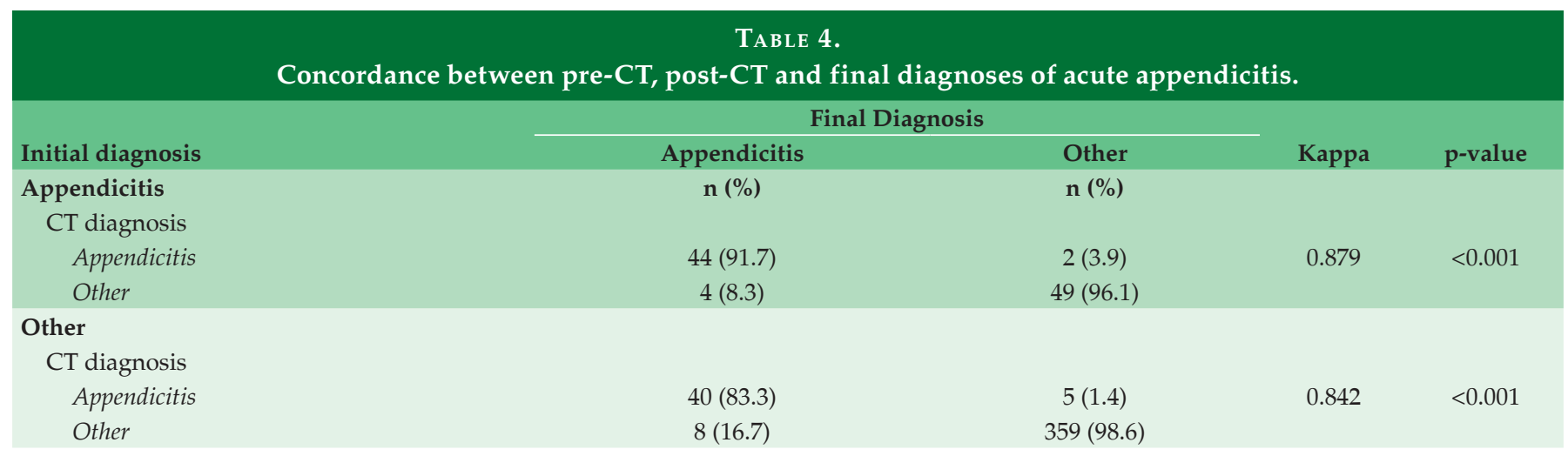

Legend: CT - Computed Tomography. $n$-absolute frequency. \% - percentage of relative frequency. Kappa-Kappa Coefficient of Concordance.

The analysis was directed to diagnoses of NSAP, OU and $\mathrm{AP}$, which together account for more than $70 \%$ of the final diagnoses. As broadly reported in other studies, the CT showed a high degree of accuracy ${ }^{1-5}$, with a moderate correlation between clinical, post-CT and final diagnoses for NSAP and OU and excellent for AP. However, patients with a final and tomographic diagnosis of NSAP, OU and AP already showed clinical suspicion in more than $50 \%$ of the cases, reaching more than $90 \%$ for patients with AP, and thus, can be considered clinically unnecessary.

In fact, a recent study showed that the use of TC in the ER did not add any improvement to the diagnosis of OU, except in cases of great diagnostic uncertainty or in patients requiring immediate surgical intervention ${ }^{22}$. Similarly, the US assessment is associated with a 50\% reduction in CT use in the ER ${ }^{23}$ and it has been considered safe in the reevaluation of patients with appendicitis $^{24}$ or even those with unspecific abdominal complaints ${ }^{25}$, without the need for ionizing radiation. In this study, $29.3 \%$ of patients were not submitted to the pre-CT US assessment and $18.8 \%$ to any other type of imaging assessment.

Moreover, pre-CT diagnoses of the main urgent diagnosed conditions were reliable, with an accuracy of over $50 \%$, exceeding $90 \%$ in cases of AP. These data indicate that CT may be used prematurely, and it raises the concern that the clinical diagnosis is being disregarded in relation to tomographic data. This reiterates the issue raised by Systermans et al. ${ }^{14}$ about a possible replacement of clinical skills by modern imaging techniques or physicians' insecurity in clinically diagnosing patients with acute conditions.

Kanzaria et $\mathrm{al}^{26}$ warned about the low reliance on clinical uncertainty by both the medical staff and patients, and the need to eliminate it at all times reinforces the idea that technology solves all problems and that an early diagnosis brings benefits without damage.
In addition to increased costs ${ }^{7}$ and exposure to ionizing radiation ${ }^{8,9}$, unnecessary examiantions may lead to incidental findings, which in turn may trigger a cascade of events involving further testing or medical procedures, of little benefit to patients ${ }^{26,27}$.

Moreover, the possibility of malpractice suits, which is often the cause of complaints against doctors ${ }^{28}$, plays a decisive role in this process. If, on the one hand, $66 \%$ of physicians believe they are responsible for ensuring that their patients are not submitted to unnecessary procedures ${ }^{13}$, fear of misdiagnosis and malpractice suits has been reported by over $60 \%$ of professionals as the main reasons for requesting diagnostic tests previously considered unnecessary by them ${ }^{26}$.

The reasons and solutions for this may have deeper roots. Among the several factors involved in the increase in the number of medical malpractice lawsuits, the most important are the deterioration in the quality of the doctor-patient relationship, together with the poor training of doctors during undergraduate and graduate training ${ }^{28}$. Lobo $^{29}$ states that, in his study site, almost all patients could not satisfactorily report the medical consultation soon going through it and that the faster the consultation, the higher the number of requested examinations, which demonstrates the deterioration of the medical-patient relationship.

Thus, since it is difficult to change professionals' habits and standards, even a legal reform may be insufficient to reduce the exaggerated use of diagnostic tests and the fight against the so-called defensive medicine can have a limited effect, if it is not developed during undergraduate medical training ${ }^{26}$.

Moreover, according to Choosing wisely, $72 \%$ of the interviewed physicians admitted requesting unnecessary exams at least once a week; $53 \%$ of them would request unnecessary exams if the patients insisted, and $70 \%$ said that patients often 
give up diagnostic tests when they are told why they are unnecessary ${ }^{13}$. Recognizing that patients are increasingly seeking information and willing to participate in the decision-making related to their cases should be currently considered ${ }^{29}$ and reinforces the need to improve crucial points, such as the development of the doctor-patient relationship and communication between doctors, patients and family members, still during the undergraduate training ${ }^{28}$.

Additionally, in the scientific literature, the high accuracy of CT in the diagnosis of AAP is well documented ${ }^{1-5}$ but information on normal CT or conditions in which CT has little influence on medical management is scarce. In this sense, an approach to the topic focusing on conditions such as age range, gender, pain duration and characteristic, complementary exams, etc., which may signal situations in which CT can be dispensed with, can be of great importance as a way to provide scientific support and increase physician confidence in indicating or contraindicating computed tomography in the ER.

Finally, although the retrospective data collection model does not allow evaluating the reasons why physicians requested the CTs considered unnecessary in the ER, the results raise the still latent question in Brazil about the increase in the use of imaging exams, which are not harmless to the patient and whose solution may have one of its most effective aspects if it is worked still during the undergraduate training of new doctors. As stated by Lobo $^{29}$, despite the use of very advanced technologies applied to medicine, doctors will still be assigned to discuss the cases with their patients and alleviate their fears, since computers lack emotions and empathy.

\section{FINAL CONSIDERATIONS}

A high number of CT scans was found to be unnecessary to diagnose the main clinically suspected diseases in the ER, whereas there was a considerable correlation between the clinical and final diagnoses. This warns of a possible depreciation of and lack of confidence in the clinical diagnosis against the overvaluation of modern medical technologies. The reasons for this may be due to nonclinical factors, such as poor patient-physician communication and fear of malpractice lawsuits, the solutions of which may have more effective effects when initiated during the undergraduate training of new professionals.

\section{REFERENCES}

1. Gangadhar K, Kielar A, Dighe MK, O'Malley R, Wang C, Gross JA, et al. Multimodality approach for imaging of non-traumatic acute abdominal emergencies. Abdom Radiol. 2016;41(1):136-48.
2. Gans SL, Pols MA, Stoker J, Boermeester MA. Guideline for the diagnostic pathway in patients with acute abdominal pain. Dig Surg. 2015;32(1):23-31.

3. Macaluso C, McNamara R. Evaluation and management of acute abdominal pain in the emergency department. Int J Gen Med [Internet]. 2012;5:789. Available from: http:/ / www.pubmedcentral.nih.gov / articlerender.fcgi?artid=34 68117\&tool=pmcentrez\&rendertype $=$ abstract

4. Viniol A, Keunecke C, Biroga T, Stadje R, Dornieden K, Bösner $S$, et al. Studies of the symptom abdominal pain a systematic review and meta-analysis. 2014;31(5):517-29.

5. Pandharipande P V., Reisner AT, Binder WD, Zaheer A, Gunn ML, Linnau KF, et al. CT in the Emergency Department: A Real-Time Study of Changes in Physician Decision Making. Radiology [Internet]. 2016;278(3):812-21. Available from: http://pubs.rsna.org/doi/10.1148/radiol.2015150473

6. Dovales ACM, Souza AA, Veiga LHS. Tomografia computadorizada no Brasil: frequência e padrão de uso em pacientes internados no Sistema Único de Saúde (SUS). Rev Bras Física Médica. 2015;9(1):11-4.

7. Institute AN. Report Medical Imaging: Is the Growth Boom Over ? Jacr. 2012;1-7.

8. Costa DMC, Salvadori PS, Monjardim RF, Bretas EAS, Torres LR, Caldana $\mathrm{RP}$, et al. When the non-contrast-enhanced phase is unnecessary in abdominal computed tomography scans? A retrospective analysis of 244 cases. Radiol Bras [Internet]. 2013;46(4):197-202. Available from: http:// www.scielo.br/scielo.php?script=sci_arttext\&pid=S0100-39842013000400197\&lng=en\&nrm=iso\&tlng=en

9. Reis A, Silva A. PIB estadual e Saúde: riqueza regional relacionada à disponibilidade de equipamentos e serviços de saúde para o setor de saúde suplementar Sumário executivo. 2014.

10. Raja AS, Ip IK, Sodickson AD, Walls RM, Seltzer SE, Kosowsky JM, et al. Radiology utilization in the emergency department: Trends of the past 2 decades. Am J Roentgenol. 2014;203(2):355-60.

11. Levin DC, Rao VM, Parker L, Frangos AJ. Continued growth in emergency department imaging is bucking the overall trends. J Am Coll Radiol [Internet]. 2014;11(11):10447. Available from: http://dx.doi.org/10.1016/j. jacr.2014.07.008

12. ABIM foundation. Choosing Wisely [Internet]. Available from: www.choosingwisely.org

13. Wisely C, Wisely C. Survey: Physicians Are Aware That Many Medical Tests and Procedures are Unnecessary, See Themselves As Solution. 2014; Available from: http:// 
www.choosingwisely.org/survey-physicians-are-aware-that-many-medical-tests-and-procedures-are-unnecessary-see-themselves-as-solution/

14. Systermans BJ, Devitt PG. Computed tomography in acute abdominal pain: An overused investigation? ANZ J Surg. 2014;84(3):155-9.

15. Obuchowski N, Modic MT. Total body screening: Predicting actionable findings. Acad Radiol. 2006;13(4):480-5.

16. Gardner CS, Jaffe TA, Nelson RC. Impact of CT in elderly patients presenting to the emergency department with acute abdominal pain. Abdom Imaging. 2015;40(7):2877-82.

17. Pennel DJL, Goergen N, Driver CP. Nonspeci fi c abdominal pain is a safe diagnosis. 2014;49:1602-4.

18. Eisenberg JD, Reisner AT, Binder WD, Zaheer A, Gunn ML, Linnau KF, et al. Role of CT in the diagnosis of nonspecific abdominal pain: A multicenter analysis. Am J Roentgenol. 2017;208(3):570-6.

19. Viera AJ, Ga M. Understa nding Interobserver Agreement: The Ka ppa Sta tistic. 2005;(May):360-3.

20. Laurell H, Hansson L-E, Gunnarsson U. Impact of Clinical Experience and Diagnostic Performance in Patients with Acute Abdominal Pain. Gastroenterol Res Pract [Internet]. 2015;2015:1-7. Available from: http:/ /www.hindawi. com/journals/grp/2015/590346/

21. Fagerström A, Paajanen P, Saarelainen H, Ahonen-Siirtola M, Ukkonen M, Miettinen $\mathrm{P}$, et al. Nonspecific abdominal pain remains as the most common reason for acute abdomen: 26-year retrospective audit in one emergency unit. Scand J Gastroenterol [Internet]. 2017;52(10):1072-7. Available from: https://doi.org/10.1080/00365521.2017.1342140

22. Westergreen-Thorne M, Lee SY, Babawale K, Lovegrove C, Brewer J, Shrotri N. Comparing the diagnostic accuracy of ultrasound in the community and in the hospital setting for urinary calculi: A retrospective cohort study. J Clin Urol. 2017;10(2):133-6.

23. Atema JJ, Gans SL, Van Randen A, Laméris W, van Es HW, van Heesewijk JPM, et al. Comparison of Imaging Strategies with Conditional versus Immediate Contrast-Enhanced Computed Tomography in Patients with Clinical Suspicion of Acute Appendicitis. Eur Radiol. 2015;25(8):2445-52.

24. Kim MS, Kwon HJ, Kang KA, Do IG, Park HJ, Kim EY, et al. Diagnostic performance and useful fndings of ultrasound re-evaluation for patients with equivocal CT features of acute appendicitis. Br J Radiol. 2018;91(1082).
25. Toorenvliet BR, Bakker RFR, Flu HC, Merkus JWS, Hamming JF, Breslau PJ. Standard outpatient re-evaluation for patients not admitted to the hospital after emergency department evaluation for acute abdominal pain. World J Surg. 2010;34(3):480-6.

26. Kanzaria HK, Hoffman JR, Probst MA, Caloyeras JP, Berry $\mathrm{SH}$, Brook RH. Emergency physician perceptions of medically unnecessary advanced diagnostic imaging. Acad Emerg Med. 2015;22(4):390-8.

27. Schifeling $\mathrm{CH}$, Williams DA. Appropriate use of imaging for acute abdominal pain. JAMA Int Med. 2017;177(12):1853-4.

28. Bitencourt AGV, Neves NMBC, Neves FBCS, Brasil ISP de S, Santos LSC dos. Análise do erro médico em processos ético-profissionais: implicações na educação médica. Rev Bras Educ Med [Internet]. 2007;31(3):223-8. Available from: http://www.scielo.br/scielo.php?script=sci arttext\&pid=S0100-55022007000300004\&lng=pt\&tlng=pt

29. Lobo LC. Inteligência artificial, o Futuro da Medicina e a Educação Médica. Rev Bras Educ Med [Internet]. 2018;42(3):3-8. Available from: http://www. scielo.br/scielo.php?script=sci_arttext\&pid=S0100$-55022018000300003 \& \operatorname{lng}=\mathrm{pt} \& \operatorname{tn} \mathrm{ln}=\mathrm{pt}$

\section{AUTHORS' CONTRIBUTION}

The authors participated in the conception and design of this project, as well as data collection and analysis, writing and revision of the manuscript.

\section{CONFLICTS OF INTERESTS}

The authors declare no conflict of interest.

\section{ADDRESS FOR CORRESPONDENCE}

Henrique Soares Silva - Rua Antônio José de Souza, n.128, bairro Luzia, 49045-440, Aracaju, Sergipe, Brasil. MD, Radiologist. Master in Health and Environment from UNIT. Tutor of the medical course at Tiradentes University (UNIT) and preceptor of the Medical Residency in Radiology and Imaging Diagnosis at the University Hospital of the Federal University of Sergipe (UFS) in Aracaju-SE.

henriquesoaressilva@yahoo.com.br 